\title{
Closer to Brussels than to Rome? The EU as the new external referent for a secularised Irish society and a redefined Catholic identity
}

Jean-Christophe Penet

\section{(2) OpenEdition \\ Journals}

Electronic version

URL: http://journals.openedition.org/etudesirlandaises/1168

DOI: 10.4000/etudesirlandaises. 1168

ISSN: 2259-8863

Publisher

Presses universitaires de Rennes

Printed version

Date of publication: 30 June 2009

Number of pages: $53-66$

ISBN: 978-2-7535-0935-1

ISSN: 0183-973X

Electronic reference

Jean-Christophe Penet, "Closer to Brussels than to Rome? The EU as the new external referent for a secularised Irish society and a redefined Catholic identity ", Études irlandaises [Online], 34.1 | 2009, Online since 30 June 2011, connection on 01 May 2019. URL : http://journals.openedition.org/ etudesirlandaises/1168; DOI : 10.4000/etudesirlandaises.1168

This text was automatically generated on 1 May 2019.

(C) Presses universitaires de Rennes 


\title{
Closer to Brussels than to Rome? The EU as the new external referent for a secularised Irish society and a redefined Catholic identity
}

\author{
Jean-Christophe Penet
}

1 It can be easily argued that from the creation of the Irish State and well into the 1960s Catholicism was at its apex in Ireland, as the institutional Church turned out to be one of the great victors of the nation's war for independence. As shown by Patsy McGarry, it was a time when "Ireland was producing so many priests and nuns that between one-third and a half of them went on the missions" ${ }^{1}$. In an article about Catholic and national identity, however, Timothy J. White shows that, despite appearances, "By the late 1950s and early 1960s, the integration of Catholicism and national identity which had delayed or prevented the secularisation that had come to the rest of Europe finally yielded to those forces associated with the arrival of industrialisation and urbanisation ${ }^{2}$." In fact, just as Irish nationalism, which had achieved most of its objectives by the 1960s, had paradoxically become exhausted at that time - as shown by the decision to apply for EEC membership in 1961 - it seems that the high point of its most faithful ally, the Catholic Church, had also already passed in Ireland by the end of that decade ${ }^{3}$. It is therefore legitimate to wonder whether Ireland's will to join in the European project was the result of or further entailed the weakening position of the Catholic Church in Ireland, and how the latter reacted to those changing circumstances. How did the Church react to the gradual crumbling down of its monopoly within Irish society at a time when the country started becoming more liberal-minded, increasingly founding its hopes on the emerging liberal and secular European Community? To try and answer this question, we shall first have a closer look at the way EEC membership has transformed the relationship between Church and State since Ireland started its liberal dawn in the late 1950s. This should lead us to note that the Church's loss of its monopoly in Ireland has not meant the 
disappearance of its influence in the public sphere. In fact, the Church has pragmatically and successfully adapted its views on the European project over the years in order to survive. This has, in turn, brought about a redefinition of its perceived role both within Irish society and within the European Union.

On an institutional level, the liberal ${ }^{4}$ dawn of the sixties started in Ireland when Seán Lemass became Taoiseach in 1959, since he engendered, along with Ken Whitaker ${ }^{5}$, what Liam Ryan calls the "creation of the second Ireland " - the one that came after de Valera's. Even though Seán Lemass had been, as minister in de Valera's government, an advocate of isolationism, he decided, as Taoiseach, that it was time for Ireland to improve its grim economy by trading isolationism for free trade. As underlined by Marie-Claire Considère-Charon: "Tandis que le projet de marché commun se consolidait peu à peu, l'Irlande allait à son tour redéfinir ses orientations et ses priorités. Une nouvelle logique économique sous le signe de l'ouverture allait se mettre en place ${ }^{7}$." Recognising that Ireland's size, its geographical location and its insularity somewhat hindered the country's economic boom, Lemass nonetheless claimed that these obstacles could be removed by a new and appropriate economic strategy. As a result, crucial policy changes were brought together in Thomas Kenneth Whitaker's seminal paper Economic Development (1958). These policies were, as shown by John Bradley, "a heady and novel mix of commitment to trade liberalisation, a range of direct and indirect grant aid to private firms, and a singular incentive of zero corporation profit tax exports ${ }^{8}$. An attractive corporation tax rate and the absence of tariffs were, however, but a beginning in the creation of this second Ireland which, according to Liam Ryan, "brought economic as well as psychological transformation to the country by providing a solid economic base ${ }^{9 "}$. It was in such a context that Ireland sent its application for EEC membership along with the British application in 1961.

3 It is true that Ireland could barely have done otherwise once the British Prime Minister Macmillan had announced the intention of the UK to apply for membership, as the 1938 Anglo-Irish Trade Agreement had made the UK Ireland's greatest trading partner. Yet there are reasons to believe that the application also corresponded to a genuine will on the part of the Irish government to join in the new economic perspective opened up by the European Economic Community. Even though the joint Anglo-Irish application was rejected due to General de Gaulle's staunch refusal to let the UK become a new EECmember - to be finally accepted in 1972 under Georges Pompidou's presidency - the seriousness with which the Irish took their application was demonstrated in the educational domain. After the war, most European countries had developed an egalitarian vision of society in which education had a key role to play. Equal educational opportunities, it was believed, would enable the disadvantaged to climb the social ladder. In Ireland, however, education had remained the stronghold of the Catholic Church, and "the Church's concentration on the humane disciplines, and its endorsement of the classical liberal education tradition had resulted in technical knowledge being undervalued ${ }^{10}$ ". In 1966, the - originally European - Organisation for Economic Cooperation and Development (OECD) published a report entitled "Investment in Education". The OECD reproached the Irish education system for having a strong degree of class differentiation at secondary and third levels and it strongly recommended a change in the Irish curricular emphasis from the classical humanist tradition championed by the Church - to "applied knowledge", that is to say to a form of knowledge that could serve economic development. In the wake of the OECD report, the 
Department of Education decided to design new school curricula that would serve the needs of an industrial economy. The Department of Education's decision to take the advice of the OECD cannot be underestimated, as it represented a fundamental philosophical shift in thinking on education. ${ }^{11}$ The government's decision to answer the needs of the Irish economy in spite of the Church's unwillingness to yield power in the educational domain and, thereby, its decision to put an end to what had been the guiding principle in education since the late $19^{\text {th }}$ century, shows that Irish politics and Irish society had already started having more secular preoccupations in the mid-1960s. Whether they were, at a political level, brought into the country by OECD reports or, at a social level, by the foreign media and their foreign programmes (and we are thinking, here, of the $\mathrm{BBC}$ ), the more secular and liberal preoccupations of most Western societies had well and truly penetrated Irish society by the end of the sixties.

In fact, the ease with which these crucial new policies were carried out and accepted in Ireland tends to show that the country was already partly secularised at that stage. Truly, one could believe that, due to the withdrawal of Irish society into an inclusive form of nationalism progressively associated with Catholicism through the $19^{\text {th }}$ century, and to the isolationism championed by the Church-State-Nation triangle in De Valera's moral community, Ireland did not experience modernity. However, this interpretation ignores the fact that one of the main characteristics of modernity was, after all, the creation of new political communities. In its efforts to "restore" the Irish nation to the way it used to be under the banner of religion, nationalism in Ireland was much more a political project - a future-oriented political belief and ideology that made ample use of the past to legitimise its present claims - than a religious one. Irish nationalists were in fact unconsciously changing the divine order by imposing their own nationalist - and therefore human - will onto this order. Even though the modern political ideology adopted by modern Ireland - its political belief - was a mix of nationalism and of Ultramontane Catholicism which rejected modern, secular values, it can be argued that Irish society started its own secularisation process from the very moment it adopted this very political ideology. Thus, despite appearances, De Valera's moral community was never completely achieved - and it was speedily dismissed once the time had come. If this explains why the changes adopted in the 1960s, and notably the decision to apply for EEC membership, were easily accepted by most of the Irish, it does not account for the Irish hierarchy's acceptance of the latter. In fact, this was probably due to the redefinition of Catholic practices and of the role of the Church in society brought about by the second Vatican Council. Started in 1962, the council, which consisted in an effort to adapt the Catholic Church to the modern world, encouraged - albeit unconsciously - the advance of secularisation, since it recognised the modern values of private judgement and of pluralism it had until then intransigently fought. With Vatican II, the Catholic Church was turning the page on the intransigent chapter of its history, no less. However reluctantly, the Irish Catholic hierarchy - which for the most part could not see any point in changing anything within the Church, as there were but few visible signs of secularisation in Ireland at the time - followed Rome's instructions, thereby remaining faithful to its tradition of unquestioning obedience to the Holy See. It consequently gave the Irish government more leeway in terms of economic policies. What is more, there is another reason why the Second Vatican Council participated in the Irish clergy's acceptance of the EEC-membership. In an article on "Religious phenomena and European Identification", Alfredo Canavero and Jean-Dominique Durand emphasised that: 


\begin{abstract}
[...] les pèlerinages à Rome, surtout ceux qui ont suivi les deux guerres mondiales, ou le concile de Vatican II, ont représenté une étape importante dans le processus d'intégration et dans la formation d'une mentalité européenne [...]. Dans une perspective originale, Dominique Gonnet a souligné ce que l'événement conciliaire a signifié pour la rencontre et les échanges entre les évêques européens après le cloisonnement des dernières années du pontificat pacellien. Il a défini le concile comme «le point d'ancrage d'une longue histoire européenne» [...]. Ce fut la solidarité entre les évêques européens et leurs sentiments communs qui permirent l'approbation de la déclaration sur la liberté religieuse Dignitatis Humanae, avec des effets importants sur le développement de l'œcuménisme et, par conséquent, une plus grande intégration parmi les peuples européens ${ }^{12}$.
\end{abstract}

5 Even though it would be fair to think that, due to Ireland's neutrality during the war and the apparent good health of Catholicism there, the Irish bishops did not share as much in the feeling of solidarity as, say, their French counterparts, this does not mean that they did not experience it at all. Upon coming back from Rome, Irish bishops were probably much more willing to show themselves more enthusiastic about Ireland's membership in the EEC than in the 1950s, be it to control the change that was bound to emerge from it. Indeed, by the mid-1960s, they were increasingly aware of the fact that Ireland was becoming visibly more secular. As confirmed by Timothy J. White:

[...] by integrating the Irish economy with those in Europe and the rest of the world, [Seán] Lemass [had] necessarily unleashed forces that would challenge not only the standard of living of the Irish but also their priorities and values in life. The materialistic mentality of the Irish proliferated as material conditions in Ireland dramatically improved in the $1960 \mathrm{~s}^{13}$.

In 1972, however, the year when its EC-membership joint application with the UK was finally accepted, Ireland still bore nearly all of the characteristics of a Third-World country. Its unbalanced economy was marked by high unemployment and emigration levels as well as by bad infrastructures and a poorly skilled and insufficient workforce ${ }^{14}$. Things were soon to change for the better, though, in the Emerald Isle, thanks to continued economic reform and massive EEC investments. Thus, as emphasised by John Bradley:

The Irish economic policy-making environment during this period can be characterised as having shifted from one appropriate to a dependent state on the periphery of the UK to that of a region more fully integrated into an encompassing European economy. Foreign Direct Investment (FDI) renovated and boosted Irish productive capacity. The Single Market provided the primary source of demand. All that remained was for a big push on improvement in physical infrastructure, education and training, and this arrived in the form of a dramatic innovation in regional policy at the EU level ${ }^{15}$.

7 The link between Ireland's EEC membership and its improving economy certainly explains why the Irish have been so favourable to the European project ${ }^{16}$. In the 1972 referendum on EEC membership, 83 per cent of the Irish voted in favour of membership ${ }^{17}$ . Fifteen years later, in the referendum on the Single European Act (May 1987), only 30 per cent of them rejected the act which was to open up an internal free market of 320 million consumers - with free movement of goods, services, people and capital ensured - 
by 31 December 1992. Economically, at least, this meant that the Irish were ready to do away with their insular mentality to adopt, instead, a more global stand. In an article published in the Jesuit magazine Studies in 1989, the then European Commissioner Irishborn Peter D. Sutherland stated that it would be unfair to characterise the positive attitude of the Irish towards Europe "as simply a reflection of the widespread understanding that membership has brought substantial economic benefit ${ }^{18}$ ". He then reminded his readers that in a survey conducted in Ireland at the end of 1988, 79 per cent expressed the belief that Ireland had gained through membership as against, for example, 47 per cent and 55 per cent respectively in the UK and West Germany. Similarly, the Catholic Church in Ireland at the time was quite zealous to show its endearment to the European project. If it did, it was probably because it was aware, at that stage, of the fact that Ireland's political ideal of a moral community was but a remnant from the past, as testified by the issue dedicated to "Secularisation in Ireland" in Studies in 1985. In the editorial of the Jesuit magazine, it was admitted that "The Republic is no longer universally Roman Catholic and Nationalist as it seemed to be in the 1950s". It was also underlined that secularisation can be seen positively, as it helps people "move away from the easy reliance on an overinstitutionalised Church to a more personal choice of faith", and therefore leads to "better religious individuals ${ }^{19}$ ". Following this idea that modernity and secularisation were forces to be reckoned with rather than fought, the Irish Catholic Church no longer had any reason to show itself half-hearted when it came to the European project. In fact, the Irish hierarchy had to embrace the European project if it wanted to influence it. This is how we can understand why the Irish bishops declared in a lengthy statement in 1979 on the occasion of the first direct election to the European Parliament: "We must go beyond the merely economic aspect of the European Community and see the desire that was there at its beginning and has remained at its heart ${ }^{20}$."

Ireland's growing integration into the European Community nevertheless remained a true challenge for the Catholic Church in Ireland, as European Laws participated in the further secularisation of the country's laws and Constitution - which had been inspired by Catholic teachings - and led, therefore, to a gradual dismantlement of the Church's moral monopoly in Irish society. The year Ireland became a member State, the Lynch government held a referendum asking the Irish to consent to the deletion of the clause in Article 44 of the 1937 Constitution which recognised the "special position" of the Catholic Church. The huge support in favour of the deletion of the clause ( 85 per cent) can nonetheless be seen as the obedience - however reluctant it might have been - of Irish Catholics to the new precepts of Vatican II that championed a more ecumenical view of religion. If this was the case, Rome and not Brussels remained Ireland's external referent at that date. One year later, in 1973, however, the same Irish Catholic hierarchy distanced itself from its until then usual, dogmatic stand during the debate over Mary Robinson's highly polemical private member's bill to liberalise the import and sale of contraceptives in the Emerald Isle. Even though the Catholic hierarchy strongly warned against the dark effects of generalising access to contraceptives, they declared: "There are many things which the Catholic Church holds to be morally wrong and no one has ever suggested, least of all the Church herself, that they should be prohibited by the State ${ }^{21}$." Rejected by the Dáil in March 1974, the bill never became law. The Fine Gael/Labour coalition led by FitzGerald that was elected in 1981 nonetheless felt boosted by this new attitude of the Catholic hierarchy towards politics and did not hide its ambition to further ensure the 
liberalisation of Irish political and social life from Catholic teachings. Soon after the election, it launched a vast "constitutional crusade" that aimed to reform Ireland's institutions by making them more secular. As Louise Fuller noted in her article on "New Ireland and the Undoing of the Catholic Legacy", developments in Irish society back then conspired to make FitzGerald's reform programme difficult, as voters remained divided between liberal and conservative camps, each wanting to define Irish identity. The new Taoiseach's crusade nonetheless set the tone for the whole of the 1980s, and the 1980s and 1990s were consequently decades of intense reform ${ }^{22}$. If some of these reforms resulted directly from the Irish government's will to secularise its laws - in February 1985, for instance, despite strong opposition from the Catholic hierarchy, Minister for Health Barry Desmond passed the Family Planning (Amendment) Act which made nonmedical contraceptives available to adults without a medical prescription - others were the direct result of the new sovereignty of Community Law. Established in 1963, the doctrine of Direct Effect provided that under certain conditions the provisions of European Law would have direct effect and might provide rights and remedies for individuals that can be enforced against Member States. This is what happened in Ireland, especially concerning the liberation of women from the traditional role in which De Valera's moral community had wanted to keep them. In article 119 of the Treaty of Rome, for example, the EEC advocated equal job opportunities between men and women. Shortly after its admission and the removal of the clause about the "special position of the Church" in the Constitution, the Irish government consequently voted in a series of laws that aimed at re-establishing equal job opportunities for women in Ireland - Employment and Married Women Act (1974), Anti-Discrimination Pay Act (1976), Employment Equality Act (1977) and, last but not least, the Social Welfare Act (1985) which guaranteed women the same right to social welfare as men ${ }^{23}$. More concretely, EC Law sometimes directly overruled some of Ireland's most "traditional" (read Catholic) laws, as was partially the case in the X case. In 1992, the Irish High Court forbade a pregnant Irish teenager who had been raped to travel abroad to interrupt her pregnancy. This decision was motivated by article 40.3.3 of the Irish Constitution whereby: "The State acknowledges the right to life of the unborn and, with due regard to the equal right to life to the mother, guarantees in its laws to respect, as far as predictable, by its laws to defend and vindicate that right ${ }^{24}$ ." In March 1992, the Supreme Court judged otherwise and repealed the teenager's travel ban. Following this decision by the Supreme Court a referendum on abortion was held in November 1992. In this referendum, $65 \%$ of Irish voters judged that suicide was a sufficient threat to justify an abortion, $60 \%$ were in favour of the right to information on abortion services and $62 \%$ of them believed that the prohibition of abortion should not limit the right to travel abroad to avail of such services. Judging by the results of the referendum, which by and large approved of the Supreme Court's decision, it seems that by the early 1990s it was not only the Irish government, but Irish civil society as a whole that had started taking Brussels instead of Rome as its new external referent, if not as its referee ${ }^{25}$. This tendency was confirmed, one year later, when a directive from the European Court of Human Rights calling for the decriminalisation of homosexual acts between two consenting adults made Ireland pass some legislation which legalised homosexuality ${ }^{26}$. According to Louise Fuller, such change shows that, in the area of social legislation, "by the 1980s and 1990s not only were bishops less able to influence politicians, but politicians themselves did not have the last word as to legislation, nor did the national courts have absolute discretion as to its interpretation ${ }^{27}$ ". European institutions now have to be reckoned with. This phenomenon, which has affected all of 
the Member States, is not specific to Ireland, but demonstrates the extent to which the latter has become integrated into the European Union in spite of its national/religious specificity.

9 No doubt, belonging to the European Union has been a permanent source of transformation for Ireland's own public space and, therefore, for its national identity. As boasted by the Department of Foreign Affairs in its website on "Ireland in Europe": "Membership has contributed to rapid progress in a range of areas including the development of agriculture, industry and services. It is estimated that 700,000 jobs have been created in Ireland during the years of membership and that trade has increased 90 fold ${ }^{28}$." As a result, the 1990s saw the creation of a so-called "Celtic Tiger Ireland" characterised by sustained high levels of economic growth. Ireland's Gross Domestic Product increased by 9.8 per cent in 1998 and by 10.7 per cent in 2000, thus turning the Irish economy into the fastest-growing economy of the whole European Community. If in 1978 Ireland's GDP was only 58 per cent of the European Community's average GDP, it had surpassed the United Kingdom's GDP in 1996 and represented 119 per cent of the European Community's average GDP in $2000^{29}$. This change in the Irish economy undeniably opened new horizons in Irish society, which gradually became more confident and outward looking. With a now transformed economy, largely opened to foreign investments and based on a thriving service industry, Ireland's sense of identity was bound to be altered by permanent contact with otherness, whether that otherness be European (due to a continued integration into the European Union) or North American (due to the huge amount of US investments in the Irish economy). To the extent that the Catholic Church in Ireland, which is now seen as just yet another organisation, no longer defines Ireland's national identity. Indeed, "Modern Ireland is the nation of the Celtic Tiger rather than the land of saints and scholars (which, it could be argued, was a rather romantic notion anyway). Gone are the days when there were no weddings and dances during Lent. Vocations to priesthood and religious life are nearly non-existent ${ }^{30}$ ". On the one hand, the privileged position of the Church in Ireland can no longer be taken for granted. On the other hand, the current redefinition of the Church does not mean, I believe, its complete disappearance from the public arena.

10 In fact, according to Tony Fahey: "Although Catholics in the Republic may be less assiduous in religious practice and more critical of the Catholic Church than in the past, they have been slow to disavow their Catholic connections entirely ${ }^{31}$." In Celtic Tiger Ireland, just as in most European societies, a redefinition of what it means to be Catholic seems to have taken place. This redefinition is characterised by a general drop in Church attendance - between 1999 and 2003, the number of regular attenders and of weekly attenders fell respectively from $76 \%$ and $83 \%$ to $70 \%$ and $64 \%{ }^{32}$ - and also by a dramatic drop in the number of people going to confession, as $47 \%$ of Irish Catholics went to confession on a monthly basis in 1974, as compared to a mere $14 \%$ in $1995^{33}$. This does not mean, however, that the link between Catholicism and today's Irish has been totally severed, but confirms the idea that "when it comes to giving expression to their beliefs, [the Irish] increasingly prefer a private to a communal setting ${ }^{34 "}$. And this is shown by the fact that 60 per cent of Irish people still pray on a regular basis, which is a way for them to maintain some sort of a connection with the next world. In Ireland's secular Tiger society, Catholic identity and belief have become privatised, individualised and, therefore, plural. The sources of definition and of legitimisation of Catholic identity and belief no longer lie, as used to be the case, in the one moral community, but, on the 
contrary, in the plurality of individuals who can either adopt them or reject them. Thus, the definition of Catholic identity has become somewhat fragmented in an Ireland where "the disaffection of the traditional Church has led many to a spiritual quest of their own ${ }^{35}$ ". This idea was clearly expressed by columnist Colum Kenney, who wrote: "Hopefully, there will never be again a uniform 'Irish Catholic' but, instead, many Irish Catholics with personal identities based on open and authentic spiritual practice ${ }^{36}$." It is not only their identity as Irish people, but also their identity as Catholics that most Irish do not expect the Roman Catholic institution to continue defining for them. Irish Catholics now want a more immediate, a more authentic and a more personal link with the next world. In doing so, they are in fact becoming more like the rest of their European counterparts. Now that the Irish choose to be Catholic - or not - in contemporary, globalised Ireland, Catholicism can no longer remain "la culture englobante de la société, même sous forme sécularisée ${ }^{37 "}$. Restructured as a subculture, Catholicism nonetheless remains influential within Irish society - and, more generally, within the European Union ${ }^{38}$ - be it as a lobby ${ }^{39}$.

11 In a now redefined Irish society, in which Catholicism has progressively become a subculture, we can wonder how Ireland now conceives of the place of Catholicism both in its own and in the European public arena. As a pro-European, Ireland's ex-Taoiseach Bertie Ahern willingly recognised that taking Brussels instead of Rome as a new external referent through EU membership had played a vital role in his country's recent success story ${ }^{40}$. Yet Bertie Ahern also believed that the one did not necessarily exclude the other. Indeed, after a visit to Pope Benedict XVI in 2005, Ahern wrote in Ireland's The Irish Times that his meeting with the Pope was "a reminder of the values at the heart of the European project": "Our future can only be shaped with confidence when we are secularly rooted in our culture and in our community. One pillar of that culture is the Christian tradition. It is a culture of community, but one with deep respect for the individual. [...] It is the foundation of our common European inheritance ${ }^{41}$." Still according to Ahern, now that Ireland has become more confident thanks to EU membership, it should become more actively involved in the European project, whether politically, economically or culturally. Back in 1989, Irish professor of moral theology Enda McDonagh already believed that:

In its closer integration with Europe, Ireland and its people with their political and intellectual leaders will have a responsibility to further the dialogue between the political and transcendent dimensions of freedom. [...]. It must also of course seek to cherish the rich, if diverse, Irish identity within an interdependent Europe in the face of any attempt at shallow homogenisation ${ }^{42}$.

12 Twenty years on, it seems that Enda McDonagh's wish has been heard by Irish politicians, who pushed for the amendment of Article 51 of the proposed European constitutional treaty (2004) so as to clarify the status of Churches in their relations with European institutions. This was done, according to Bertie Ahern, because "structured dialogue with the churches offers the opportunity to listen anew in an open and transparent way to an inner voice in the Irish and European tradition." ${ }^{43}$ For the same reason, Ireland encouraged the mention of Europe's common past Christian heritage in the European constitution's preamble, while more fiercely secular countries such as France largely objected to it. Is Ireland therefore a country with a mission in the European public sphere? According to current editorialist of Studies, Fergus O'Donoghue,

Ireland [...] has become so much a part of the European project that we are now at its heart. Our recent membership of the UN Security Council shows that we are able to punch well above our weight. Our attempt to have God mentioned in the EU Constitution was itself a sign that we defend traditions and values, even when some 
commentators see them as "outmoded". We can reaffirm the values that are the basis of the European ideal and can affirm the need for ever-closer cooperation ${ }^{44}$. largely arguable. It is undeniable, however, that Ireland's more active role, of late, in the shaping of EU institutions and of their relations to Europe's Churches challenges France's definition of a secular Europe ! If, as shown recently by the Millward Brown IMS opinion poll carried out on the no vote in the Lisbon referendum (12 June 2008), the main reason for Irish people to have voted no to the Treaty was "lack of understanding or understanding" of what they were asked to vote on (42\%), the other two main reasons were the fear that "the introduction of a conscription into a European army was included in the treaty" (33\%) and the fear that "it would end Ireland's control over the country's abortion policy ${ }^{45}$ ". If these reasons were the ones given by the people having voted no, they were probably widely shared in Ireland, as $67 \%$ of respondents of a Eurobarometer poll considered that the "no" campaign was the more convincing one ${ }^{46}$. No matter what one thinks about those fears, they corroborate the idea that a considerable part of the Irish are still endeared to the principle of neutrality and to Catholic teachings in social matters, and that they want to defend them in (spite of) Brussels. This does not mean, however, that the Irish are now shying away from Brussels. In spite of the victory of the no vote, "60 per cent of voters felt that Ireland's interests were best pursued by remaining fully involved in the EU ${ }^{47}$ ". A view shared by the island's new Taoiseach, Brian Cowen, who recently emphasised " [...] the imperative for Ireland to be fully engaged with our partners in the European Union" in Fianna Fáil parliamentary party in Galway ${ }^{48}$. Faring in a sea of serious global economic trouble, Ireland is aware of the importance to embrace the European project, be it to better control it. It does not seem willing, however, to sacrifice its Catholic heritage - still too often misleadingly confused for its national identity - to do so. This is why it is now more than time that one started studying in greater detail the influence both of Ireland as a Member State and of Irish Catholicism as a lobby in Brussels, on Europe's emerging public sphere - defined as "[...] l'arène d'expression des engagements collectifs et des allégeances, le lieu où se nouent les interactions de ces variables avec les pratiques et les discours de pouvoir ${ }^{49}$ - and more specifically on Europe's perception of the role of religions in this public sphere. Will David, once more, triumph over Goliath?

\section{NOTES}

1. Patsy McGarry, "The Rise and Fall of Roman Catholicism in Ireland" in Louise Fuller, John Littleton and Eamon Maher (eds.), Irish and Catholic. Towards an Understanding of Identity, Dublin, The Columba Press, 2006, pp. 31-44, p. 32.

2. Timothy J. White, "Decoupling Catholic and National Identity: Secularisation Theories in the Irish Context." Ibid., pp. 238-255, p. 244. 
3. Toney Fahey, B.C Hayes and R. Sinnott (eds.), Conflict and Consensus: A Study of Values and Attitudes in the Republic of Ireland and Northern Ireland, Dublin, Institute of Public Administration, 2005, p. 31.

4. The adjective liberal is used to describe social, economic and political views throughout this article. All three are derived from the elaboration, during the Enlightenment, of liberalism as an ideology advocating that politics should first and foremost protect individual rights and maximise individual freedom of choice. When used to describe social attitudes, it refers to a certain openness to the introduction of new ideas and to proposals of social reforms. When used in relation to politics, it refers to the belief that individuals should pursue their lives according to their own perception of the good and that the State should generally not dictate morality. Similarly, when used to describe economic perspectives, the word liberal refers to the idea that the state should not intervene too much in the economic realm and that an open economy should be preferred, therefore, to protectionism. Lastly, it is also used to describe the church's classic perception of education in Ireland until the 1960s. In that context, the adjective liberal is to be understood in its original meaning as "Directed to general intellectual enlargement and refinement; not narrowly restricted to the requirements of technical or professional training" in The Oxford English Dictionary, Volume VIII ( $2^{\text {nd }}$ edition), Oxford, Oxford University Press, 1991, p. 881.

5. Ken Whitaker (1916- ) became Secretary of the Department of Finance in 1956. It was in this position that he became the author of the First Programme for Economic Expansion, a White Paper that was released in 1958 and that advocated the reform and liberalisation of Ireland's economy.

6. Michael Fogarty, Liam Ryan and Joseph Lee (eds.), Irish Values and Attitudes. The Irish Report of the European Value System, Dublin, Dominican Publications, 1984, p. 101.

7. Marie-Claire Considère-Charon, Irlande: une singulière intégration européenne, Paris, Economica, 2002, p. 27.

8. John Bradley, “Managing Globalisation: Ireland's Experience in Attracting Foreign Investment" in Catherine Maignant, (dir.), Le tigre celtique en question. L'Irlande contemporaine: économie, Etat, société, Caen, PU Caen, 2007, pp. 12-25, p. 19.

9. Fogarty, op. cit., p. 101.

10. Louise Fuller, Irish Catholicism Since 1950: The Undoing of a Culture, Dublin, Gill\&Macmillan, 2002, p. 149.

11. Ibid., p. 151.

12. Alfredo Canavero and Jean-Dominique Durand, "Les phénomènes religieux et l'identification européenne" in Frank Robert (dir.), Les Identités européennes au $\mathrm{XX}^{e}$ siècle. Diversités, convergences et solidarités, Paris, Publications de la Sorbonne, 2004, pp. 145-164, p. 152.

13. Timothy J. White, "Nationalism VS. Liberalism in the Irish Context: From a Postcolonial Past to a Postmodern Future" in Eire-Ireland, An Interdisciplinary Journal of Irish Studies, Vol. 38, n 3-4, 2002, pp. 25-37, p. 31.

14. Considère-Charon, op. cit., p. 9.

15. Bradley, op. cit., p. 24.

16. Ireland's support for the EU project continues despite the recent No vote in the Lisbon referendum. Released in The Irish Times in September 2008, the Millward Brown IMS 
opinion poll on the Lisbon No vote carried out for the government clearly showed that, despite the outcome, " 60 per cent of voters felt that Ireland's interests were best pursued by remaining fully involved in the EU." The Irish Times, 10 September 2008.

17. Considère-Charon, op. cit., p. 51.

18. Peter D. Sutherland, "Ireland: Where do we stand on European Integration?" in Studies , vol. 78, n 311, 1989, pp. 243-254, p. 248.

19. Editorial, Studies, vol. 74, nº 293, 1985, p. 10.

20. Quoted from Jerome Connolly, "The Irish Churches and Foreign Policy" in Studies, vol. 77, n 395, 1988, pp. 55-67, p. 59.

21. The Irish Independent, 26 November 1973.

22. Louise Fuller, "New Ireland and the Undoing of the Catholic Legacy: Looking Back to the Future", in Louise Fuller, John Littleton and Eamon Maher (eds.), Irish and Catholic. Towards an Understanding of Identity. Dublin, The Columba Press, 2006, pp. 68-87, p. 82.

23. Considère-Charon, op. cit., p. 172.

24. Bunreacht na hEireann, article 40.3.3.

25. As pointed out by Maire Nic Ghiolla Phadraig: "The advance consultation with the hierarchy on policies of legislation impinging on sex, family life, or education gave way to informing them in advance, and then to the 1992 statement by An Taoiseach that he had no intention of talking to the bishops about the wording of an abortion referendum, and the 1993 permission for condom-vending machines again without notice to the bishops. The state, of course, has had a new external referent since joining the European Community and looks to Brussels rather than Rome for approval of policies as well as for financial support." in "The Power of the Catholic Church in the Republic of Ireland", in Patrick Clancy et al., Irish Society, Sociological Perspectives, Dublin, Institute of Public Administration, 1995, pp. 593-619, p. 612.

26. As shown by Louise Fuller, this is to be contrasted with what had happened 10 years earlier, when "[...] the Supreme Court had rejected an appeal by David Norris to declare that two Acts inherited from the period of British rule were unconstitutional and cited the preamble to the 1937 Constitution, which points to the people of Ireland as 'humbly acknowledging their obligation to Our Divine Lord Jesus Christ' as the reason for their rejection of the plea [to decriminalise homosexuality]", Fuller 2002, op. cit., p. 85.

27. Fuller 2006, op. cit., p. 85.

28. http://www.dfa.ie/home/index.aspx ?id=28457\&media=print [Accessed 14 March 2008].

29. Considère-Charon, op. cit., p. 55.

30. John Littleton, "Catholic Identity and the Irish Context" in Louise Fuller, John Littleton and Eamon Maher (eds.), Irish and Catholic. Towards an Understanding of Identity, Dublin, The Columba Press, 2006, pp. 12-30, p. 29.

31. Fahey, B. C. Hayes and R. Sinnott (eds.), Conflict and Consensus: A Study of Values and Attitudes in the Republic of Ireland and Northern Ireland, Dublin, Institute of Public Administration, 2005, p. 55.

32. Ibid., p. 43.

33. Marguerite Corish, "Pratiques et croyances religieuses, valeurs morales" in Paul Brennan (dir.), La sécularisation en Irlande, Caen, Presses universitaires de Caen, 1998, p. 140. 
34. Eoin Cassidy (ed.), Measuring Ireland. Discerning Values and Beliefs, Dublin, Veritas, 2002, p. 29.

35. Catherine Maignant, "Re-Imagining Transcendence in the Global Village" in Eamon Maher and Michael Böss, Engaging Modernity, Dublin, Veritas, 2003, pp. 71-84, p. 74.

36. Colum Kenney, “'God Help Us!': The Media and Irish Catholicism” in Louise Fuller, John Littleton and Eamon Maher (eds.), Irish and Catholic. Towards an Understanding of Identity, Dublin, The Columba Press, 2006, pp. 89-103, p. 102.

37. Jean-Paul Willaime, "L'évolution de la place du religieux dans la société" in Cahiers Français, $n^{\circ} 340$, septembre-octobre 2007, pp. 3-7, p. 8.

38. See to that effect Bérengère Massignon's study of the impact of religions - including Catholicism - on the European Union in Brussels entitled Des dieux et des fonctionnaires. Religions et laïcités face au défi de la construction européenne, Rennes, Presses Universitaires de Rennes, 2007.

39. Concerning the self-definition by the Catholic lobby of its role in the European public arena, see François Foret and Philip Schlesinger, "Le religieux dans la légitimation de l'Union européenne" in François Foret (ed.), L'espace public européen à l'épreuve du religieux, Bruxelles, Editions Libres de Bruxelles, 2007, pp. 229-249, pp. 244-245.

40. "As a country Ireland is now more successful, more confident and optimistic than at any time since the foundation of the State. We are a country transformed. And our EU membership has played a vital role in this transformation. We must not forget this. We must not take it for granted." Bertie Ahern, "Where does the European Union go now?" in Studies, vol. 94, n³75, Autumn 2005, pp. 227-236, p. 231.

41. Bertie Ahern, "Meeting with Pope a reminder of values at heart of European project" in The Irish Times, 7 July 2005.

42. Enda McDonagh, "Europe, the Faith and Ireland" in Studies, vol. 78, n 311, Autumn 1989, pp. 255-261, p. 260.

43. The Irish Times, 7 July 2005.

44. Studies, vol. 93, n 369, Spring 2004, p. 6.

45. The Irish Times, 10 September 2008. In fact, those figures confirm those of the Flash Eurobarometer report released in July 2008: http://ec.europa.eu/public_opinion/flash/ fl_245_full_en.pdf[Accessed 9 September 2008].

46. Ibid.

47. The Irish Times, 10 September 2008.

48. Ibid.

49. François Foret, "Introduction", L'espace public européen à l'épreuve du religieux, op. cit., p. 11. 


\section{ABSTRACTS}

As soon as Ireland submitted its first application for EEC membership in 1961, Brussels became another external referent alongside Rome for an Irish society that increasingly looked to outside influences. If the Irish Catholic Church first was reluctant for Ireland to join in the European project, it soon realised the importance of embracing the project, if only to control it. Brussels has nonetheless seriously challenged Rome's position as Ireland's main external point of reference in the last four decades, to the extent that the Irish Catholic Church is now perceived as yet another institution. It remains, however, quite influential in Irish politics and so a force to be reckoned with when it comes to analysing the island's perception of the European project. The present article consists above all of a general review of the way EEC membership has transformed the relationship between Church and State in Ireland for almost fifty years now.

Dès que l'Irlande soumit sa première demande d'adhésion à la CEE, Rome cessa d'être la principale source de référence étrangère pour faire place à Bruxelles dans cette société s'ouvrant progressivement sur l'extérieur. Si l'Église catholique d'Irlande vit tout d'abord d'un mauvais œil cette volonté de l'île de se joindre au projet européen, elle se rendit tout de même vite compte de l'importance d'embrasser l'initiative, ne serait-ce que pour mieux la contrôler. Bruxelles n'en est pas moins devenue un sérieux adversaire de l'hégémonie romaine en Irlande depuis bientôt un demi-siècle, à tel point que l'Église catholique y est désormais perçue comme une institution parmi d'autres. Cependant, son influence en politique persiste et elle demeure une force non négligeable pour toute analyse de la perception de l'Europe par l'Irlande. Le présent article se veut avant tout une revue générale de la manière dont l'adhésion à la CEE a fait évoluer la relation entre Eglise et Etat en Irlande depuis un peu moins de cinquante ans maintenant.

\section{INDEX}

Mots-clés: Église catholique d'Irlande, Union Européenne / CEE, sécularisation, identité nationale

Keywords: Irish Catholic Church, national identity, secularization, European Union / EEC

\section{AUTHOR}

\section{JEAN-CHRISTOPHE PENET}

NCFIS Dublin 